\title{
Circulating Tumor Cell
}

National Cancer Institute

\section{Source}

National Cancer Institute. Circulating Tumor Cell. NCI Thesaurus. Code C63797.

A metastatic cancer cell found in the peripheral blood. 